\title{
Dactylosporangium tropicum sp. nov., isolated from soil
}

\author{
Chitti Thawai, ${ }^{1,2}$ Somboon Tanasupawat ${ }^{3}$ and Takuji Kudo ${ }^{4}$
}

Correspondence

Chitti Thawai

ktchitti@kmitl.ac.th

\author{
${ }^{1}$ Department of Biology, Faculty of Science, King Mongkut's Institute of Technology Ladkrabang, \\ Bangkok 10520, Thailand \\ ${ }^{2}$ Microbial Resource Management Unit, Scientific Instrument Center, Faculty of Science, \\ King Mongkut's Institute of Technology Ladkrabang, Bangkok 10520, Thailand \\ ${ }^{3}$ Department of Microbiology, Faculty of Pharmaceutical Sciences, Chulalongkorn University, \\ Bangkok 10330, Thailand \\ ${ }^{4}$ Japan Collection of Microorganisms, RIKEN BioResourceCenter, Wako, Saitama 351-0198, \\ Japan
}

\begin{abstract}
Two novel actinomycete strains, designated $\mathrm{KB} 2-4^{\top}$ and $\mathrm{KB} 9-2$, were isolated from soil samples. Both isolates formed finger-shaped sporangia on short sporangiophores that emerged directly from substrate hyphae. The cell-wall peptidoglycan contained glutamic acid, glycine, alanine and meso-diaminopimelic acid; the whole-cell sugars were galactose, glucose, mannose, rhamnose, ribose and xylose. The diagnostic phospholipid was phosphatidylethanolamine. The predominant menaquinones were MK- $9\left(\mathrm{H}_{8}\right)$ and MK- $9\left(\mathrm{H}_{6}\right)$. Mycolic acids were not detected. The predominant cellular fatty acids $(>20 \%)$ were iso- $\mathrm{C}_{16: 0}$ and anteiso- $\mathrm{C}_{17: 0}$. For both strains, the $\mathrm{G}+\mathrm{C}$ content of the genomic DNA was about $72 \mathrm{~mol} \%$. The morphological and chemotaxonomic characteristics of the two strains were typical of members of the genus Dactylosporangium. Phylogenetic analysis using 16S rRNA gene sequences also indicated that these strains should be classified in the genus Dactylosporangium and showed that the closest relative was Dactylosporangium salmoneum NRRL B-16294 ${ }^{\top}$ (99.1\% $16 \mathrm{~S}$ rRNA gene sequence similarity). DNA-DNA relatedness and some physiological and biochemical properties indicated that the isolates could be readily distinguished from their closest phylogenetic relatives. On the basis of these phenotypic and genotypic data, the isolates represent a novel species, for which the name Dactylosporangium tropicum sp. nov. is proposed. The type strain is strain KB2-4 $4^{\top}$ $\left(=\mathrm{BCC} 34760^{\top}=\mathrm{JCM} 15673^{\top}\right)$.
\end{abstract}

The genus Dactylosporangium Thiemann et al. (1967) belongs to the family Micromonosporaceae in the order Actinomycetales (Zhi et al., 2009). This genus has proved to be an important source of pharmaceutically useful metabolites, notably antibiotics (Goodfellow, 1988). Members of the genus Dactylosporangium normally form both finger-shaped sporangia and globose bodies directly on substrate hyphae. At the time of writing, the genus Dactylosporangium encompasses 11 species with validly published names: D. aurantiacum (Thiemann et al., 1967), D. thailandense (Thiemann et al., 1967; Thiemann, 1970), D. matsuzakiense (Shomura et al., 1980), D. vinaceum (Shomura et al., 1983), D. roseum (Shomura et al., 1985),

The GenBank/EMBL/DDBJ accession numbers for the 16S rRNA gene sequences of strains $K B 2-4^{\top}$ and $K B 9-2$ are $A B 454508$ and AB543492, respectively.

Two supplementary tables are available with the online version of this paper.
D. fulvum (Shomura et al., 1986), D. darangshiense (Seo \& Lee, 2010), D. maewongense (Chiaraphongphon et al., 2010) and the three species described by Kim et al. (2010), D. luridum, D. luteum and D. salmoneum. During an investigation of novel actinomycetes from soil near a hot spring in a tropical forest in Kanchanaburi Province, Thailand, we isolated strains $\mathrm{KB} 2-4^{\mathrm{T}}$ and $\mathrm{KB} 9-2$ that showed morphological and chemotaxonomic characteristics typical of the genus Dactylosporangium, but the isolates were genotypically and phenotypically distinct from all Dactylosporangium species with validly published names.

Samples were taken from the soil surface and kept at $4{ }^{\circ} \mathrm{C}$. The samples were air-dried at room temperature for 8 days. Dried soil $(1 \mathrm{~g})$ was treated with $1.5 \%(\mathrm{v} / \mathrm{v})$ phenol in sterile distilled water $(9 \mathrm{ml})$ and diluted serially in distilled water as recommended by Hayakawa et al. (1991). Both strains were isolated on humic acid-vitamin agar supplemented with $\left(1^{-1}\right) 25 \mathrm{mg}$ nalidixic acid, $50 \mathrm{mg}$ 
cycloheximide and $1 \mathrm{mg}$ terbinafin. Purified cultures were preserved at $-80{ }^{\circ} \mathrm{C}$ and by freeze-drying.

Cell morphology was observed by light and scanning electron microscopy (JSM-5410 LV; JEOL) after growth on modified soil extract agar $\left[0.5 \mathrm{~g} \mathrm{CaSO}_{4} .2 \mathrm{H}_{2} \mathrm{O}, 0.25 \mathrm{~g}\right.$ $\mathrm{Ca}\left(\mathrm{NO}_{3}\right)_{2} .4 \mathrm{H}_{2} \mathrm{O}, 0.05 \mathrm{~g} \mathrm{MgSO} 4.7 \mathrm{H}_{2} \mathrm{O}, 0.03 \mathrm{~g} \mathrm{~K}_{2} \mathrm{SO}_{4}$, $0.02 \mathrm{~g} \mathrm{KH} \mathrm{KHO}_{4}, 0.1 \mathrm{~g} \mathrm{NaHCO}_{3}, 0.02 \mathrm{~g} \mathrm{CaCl}_{2} .2 \mathrm{H}_{2} \mathrm{O}$, $0.1 \mathrm{~g}$ yeast extract, $0.1 \mathrm{~g}$ Casamino acids, $0.2 \mathrm{~g}$ glucose, $100 \mathrm{ml}$ soil extract (Hamaki et al., 2005), $18 \mathrm{~g}$ agar, $900 \mathrm{ml}$ distilled water; $\mathrm{pH}$ 7.0]. Cells for scanning electron microscopy were prepared as described elsewhere (Itoh et al., 1989). Phenotypic characteristics were examined by using several standard methods. Cultural characteristics were tested using 14 -day-old cultures grown at $30{ }^{\circ} \mathrm{C}$ on various agar media. The Jacal Colour Card L2200 (Japan Colour Research Institute) was used for determining colour designations. Hydrolysis of various compounds and acid production from carbon sources were examined using the basal medium recommended by Gordon et al. (1974). Conditions for growth (temperature, $\mathrm{pH}$ and $\mathrm{NaCl}$ concentration) were determined on yeast extract-malt extract agar (ISP 2; Shirling \& Gottlieb, 1966) for 14 days at $30{ }^{\circ} \mathrm{C}$ (varied for growth temperature determination). Carbon-source utilization was tested on ISP 9 (Shirling \& Gottlieb, 1966) supplemented with a final concentration of $1 \%$ carbon source and $0.05 \%$ Casamino acids. Gelatin liquefaction, milk peptonization, nitrate reduction and starch hydrolysis were determined through cultivation on various media as described by Arai (1975) and Williams \& Cross (1971). The results are given in detail in the species description and Table 1. Strains $\mathrm{KB} 2-4^{\mathrm{T}}$ and $\mathrm{KB} 9-2$ possessed some distinct chemotaxonomic and phenotypic characteristics that separated them from their closest phylogenetic neighbour, D. salmoneum NRRL B-16294 . In particular, the absence of 3-hydroxy-meso-diaminopimelic acid in the cell-wall hydrolysates, the peptonization of milk, the inability to liquefy gelatin and the inability to utilize cellobiose, D-fructose, melibiose, D-xylose, lactose and L-rhamnose were effective to discriminate between strains $\mathrm{KB} 2-4^{\mathrm{T}}$ and $\mathrm{KB} 9-2$ and closely related organisms.

For chemotaxonomic analysis, freeze-dried cells were obtained from cultures grown in ISP 2 broth on a rotary shaker at $30{ }^{\circ} \mathrm{C}$ for 4 days. The cell-wall peptidoglycan was prepared and hydrolysed by the method of Kawamoto et al. (1981) and the amino acid composition was analysed by TLC (Lechevalier \& Lechevalier, 1980). The isomer of diaminopimelic acid in the cell wall was determined by the method of Staneck \& Roberts (1974). The acyl group of muramic acid in the peptidoglycan was determined by the method of Uchida \& Aida (1984). The reducing sugars from whole-cell hydrolysates were analysed by the cellulose TLC method of Komagata \& Suzuki (1987). Phospholipids in cells were extracted and analysed by the method of Minnikin et al. (1984). Fatty acid methyl ester analysis was performed by GLC according to the instructions of the Sherlock Microbial Identification System version 4.5 (Sasser, 1990; Kämpfer \& Kroppenstedt, 1996) with the
Table 1. Differential characteristics of strains $K B 2-4^{\top}$ and KB9-2 and their closest phylogenetic relatives

Strains: 1, Dactylosporangium tropicum sp. nov. KB2-4 ${ }^{\mathrm{T}} ; 2, D$. tropicum sp. nov. KB9-2; 3, D. salmoneum NRRL B-16294 ${ }^{\mathrm{T}}$; 4, D. vinaceum NBRC $14181^{\mathrm{T}} ; 5$, D. matsuzakiense NBRC $14259^{\mathrm{T}}$. All data were taken from this study. DR, Deep red; O, orange; POY, pale orangeyellow; PY, pale yellow; VR, vivid red; Y, yellow; +, positive; $\mathrm{W}$, weakly positive; - , negative.

\begin{tabular}{|lccccc|}
\hline Characteristic & $\mathbf{1}$ & $\mathbf{2}$ & $\mathbf{3}$ & $\mathbf{4}$ & $\mathbf{5}$ \\
\hline Colony colour (ISP 2) & POY & Y & Y & VR & O \\
Soluble pigment colour (ISP 2) & PY & PY & - & DR & PY \\
3-OH-meso-diaminopimelic acid & - & - & + & + & + \\
Gelatin liquefaction & - & - & + & + & - \\
Nitrate reduction & + & + & + & - & - \\
Milk peptonization & + & + & - & + & - \\
Starch hydrolysis & + & + & + & + & - \\
Growth at 37 ${ }^{\circ}$ & + & + & + & - & - \\
Minimum pH tolerance & 5 & 5 & 4 & 6 & 6 \\
Utilization of: & & & & & \\
Cellobiose & - & - & + & $\mathrm{W}$ & $\mathrm{W}$ \\
D-Fructose & - & - & + & + & $\mathrm{W}$ \\
D-Galactose & + & + & $\mathrm{W}$ & + & - \\
D-Mannitol & + & $\mathrm{W}$ & + & + & + \\
Melibiose & - & - & + & $\mathrm{W}$ & $\mathrm{W}$ \\
Raffinose & $\mathrm{W}$ & $\mathrm{W}$ & + & $\mathrm{W}$ & + \\
D-Xylose & - & - & + & + & - \\
Glycerol & + & + & + & $\mathrm{W}$ & + \\
Lactose & - & - & + & $\mathrm{W}$ & - \\
L-Arabinose & + & + & $\mathrm{W}$ & $\mathrm{W}$ & $\mathrm{W}$ \\
L-Rhamnose & - & - & $\mathrm{W}$ & + & $\mathrm{W}$ \\
\hline
\end{tabular}

TSBA40 MIDI database. The presence of mycolic acids was investigated by the method of Minnikin et al. (1975). Isoprenoid quinones were extracted by the method of Collins et al. (1977) and analysed by HPLC using a Cosmosil $5 \mathrm{C}_{18}$ column $(4.6 \times 150 \mathrm{~mm}$; Nacalai Tesque $)$. The elution solvent was methanol/2-propanol $(2: 1, \mathrm{v} / \mathrm{v})$.

Chromosomal DNA was isolated from cells grown in ISP 2 broth according to the method of Tamaoka (1994). The $\mathrm{G}+\mathrm{C}$ content of the DNA was determined using the HPLC method of Tamaoka \& Komagata (1984) and an equimolar mixture of nucleotides (Yamasa Shoyu) as the quantitative standard. DNA-DNA hybridization was conducted in microdilution-well plates, as reported by Ezaki et al. (1989). DNA-DNA relatedness was determined using the colorimetric method (Verlander, 1992). PCR-mediated amplification of the 16S rRNA gene and sequencing of the PCR products were carried out as described elsewhere (Suriyachadkun et al., 2009). The 16S rRNA gene sequence was aligned with selected sequences obtained from public databases using CLUSTAL W version 1.81 (Thompson et al., 1994). The alignment was manually verified and adjusted prior to the construction of phylogenetic trees using the neighbour-joining (Saitou \& Nei, 1987) and maximumparsimony (Kluge \& Farris, 1969) methods in MEGA version 
2.1 (Kumar et al., 2001). The confidence values of nodes were determined by using bootstrap analysis (Felsenstein, 1985) based on 1000 resamplings. 16S rRNA gene sequence similarity among all members of recognized species of the genus Dactylosporangium was determined by using the EzTaxon server (Chun et al., 2007) and, among closely related strains, was calculated manually after pairwise alignment using CLUSTAL X (Thompson et al., 1997). Gaps and ambiguous nucleotides were eliminated from the calculations.

Strains KB2-4 ${ }^{\mathrm{T}}$ and KB9-2 exhibited morphological and chemical properties of the genus Dactylosporangium (Thiemann et al., 1967; Shomura et al., 1983). Colonies of both isolates were compact and raised and produced well-developed, branched substrate hyphae, but lacked aerial hyphae. Growth was good on ISP 2, oatmeal agar (ISP 3) and inorganic salts-starch agar (ISP 4). Colonies were pale orange-yellow. A pale-yellow soluble pigment was produced in ISP 2 medium. The isolates formed groups of finger-shaped sporangia on short sporangiophores that emerged directly from substrate hyphae (Fig. 1). The sporangium surface was smooth. Each sporangium contained a row of ovoid motile spores $(0.9-1.1 \mu \mathrm{m})$. Globose bodies were observed on modified soil extract agar and humic acid-vitamin agar.

Strains KB2- $4^{\mathrm{T}}$ and KB9-2 had identical chemotaxonomic characteristics and these were similar to those of members of the genus Dactylosporangium. Cell-wall hydrolysates of both isolates contained glutamic acid, glycine, alanine and meso-diaminopimelic acid, indicating that this isolate had the cell-wall chemotype II of Lechevalier \& Lechevalier (1970). The acyl type of the cell-wall muramic acid was glycolyl. Galactose, glucose, mannose, rhamnose, ribose and xylose were found as whole-cell sugars. The characteristic phospholipids were diphosphatidylglycerol, phosphatidylglycerol, phosphatidylinositol and phosphatidylethanolamine, but not phosphatidylcholine. This pattern corresponds to phospholipid type PII of Lechevalier et al. (1977). The major

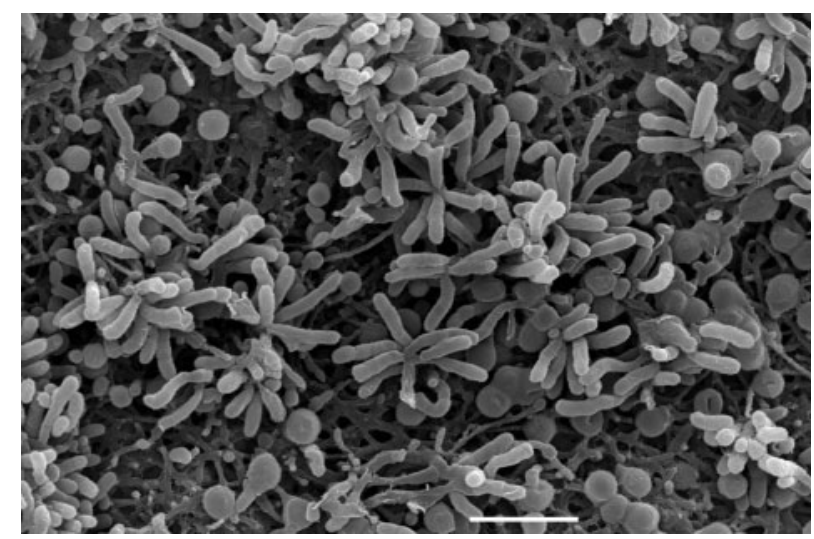

Fig. 1. Scanning electron micrograph of sporangia and globose bodies of strain $\mathrm{KB} 2-4^{\top}$ grown on humic acid-vitamin agar for 4 weeks at $28^{\circ} \mathrm{C}$. Bar, $5 \mu \mathrm{m}$. cellular fatty acids $(>2 \%)$ were iso- $\mathrm{C}_{16: 0}$, anteiso- $\mathrm{C}_{17: 0}$, iso$\mathrm{C}_{15: 0}$, anteiso- $\mathrm{C}_{15: 0}$, iso- $\mathrm{C}_{17: 0}, \mathrm{C}_{16: 0}, \mathrm{C}_{17: 0}$ and $\mathrm{C}_{18: 0}$ and the isolates also contained 10-methyl- $\mathrm{C}_{17: 0}$ (Supplementary Table S1, available in IJSEM Online). This pattern corresponds to fatty acid type $3 \mathrm{~b}$ of Kroppenstedt (1985). Mycolic acids were absent. The predominant menaquinones of strains KB2- $4^{\mathrm{T}}$ and KB9-2 were MK-9 $\left(\mathrm{H}_{8}\right) \quad(46.9$ and $48.8 \%$, respectively) and MK-9 $\left(\mathrm{H}_{6}\right)$ (39.9 and $41.1 \%$, respectively). The $\mathrm{G}+\mathrm{C}$ content of the genomic DNA was $72.5 \mathrm{~mol} \%$ for strain KB2-4 $4^{\mathrm{T}}$ and $72.2 \mathrm{~mol} \%$ for strain KB9-2.

Almost-complete $16 \mathrm{~S}$ rRNA gene sequences were obtained for strains KB2-4 ${ }^{\mathrm{T}}$ and KB9-2 (1452 and $1456 \mathrm{nt}$, respectively). The sequences exhibited a close relationship between the isolates and members of the family Micromonosporaceae. Both isolates were placed within the genus Dactylosporangium and formed a distinct lineage in a subcluster that also contained $D$. salmoneum NRRL B-16294 ${ }^{\mathrm{T}}$, which was supported by a moderate bootstrap value $(51 \%$ in the neighbour-joining tree; Fig. 2). The relationship between the isolates and $D$. salmoneum NRRL B-16294 ${ }^{\mathrm{T}}$ was also supported by the result of the maximum-parsimony analysis. 16S rRNA gene sequence similarity between strains KB2- $4^{\mathrm{T}}$ and KB9-2 and the type strains of all species of the genus Dactylosporangium with validly published names ranged from $98.0 \%(D$. thailandense IFO $12593^{\mathrm{T}}$ ) to $99.1 \%$ (D. salmoneum NRRL $\left.\mathrm{B}-16294^{\mathrm{T}}\right)$. The isolates shared $100 \%$ 16S rRNA gene sequence similarity with each other.

Low DNA-DNA relatedness (from $20.6 \pm 1.2$ to $38.8 \pm 0.9 \%$ ) was observed between the isolates and their close phylogenetic relatives (Supplementary Table S2, available in IJSEM Online). DNA-DNA relatedness between strains KB2-4 ${ }^{\mathrm{T}}$ and KB9-2 ranged from $91.2 \pm 0.7$ to $93.8 \pm 1.3 \%$ and between strain KB2-4 ${ }^{\mathrm{T}}$ and $D$. salmoneum $\mathrm{JCM} 3272^{\mathrm{T}}$ was $36.7 \pm 0.4 \%$.

It is evident from the phenotypic, chemotaxonomic and phylogenetic data that strains KB2 $-4^{\mathrm{T}}$ and KB9-2 can be distinguished from the members of previously described species of the genus Dactylosporangium. It is therefore proposed that these strains be classified in a novel species, with the name Dactylosporangium tropicum sp. nov.

\section{Description of Dactylosporangium tropicum sp. nov.}

Dactylosporangium tropicum [tro'pi.cum. L. neut. adj. tropicum tropical, of or pertaining to the tropic(s), relating to isolation from a tropical forest].

Gram-positive, mesophilic actinomycete that forms smoothsurfaced finger-shaped sporangia on short sporangiophores directly from the substrate hyphae. Colonies are pale orangeyellow on ISP 2. Each sporangium contains a row of ovoid motile spores. Globose bodies are observed on modified soil extract agar and humic acid-vitamin agar. Aerial mycelium is absent. Spore surface appears smooth. A pale-yellow soluble pigment is produced on ISP 2. Nitrate is reduced to nitrite. Utilizes D-galactose, D-mannitol, glycerol and L-arabinose, 


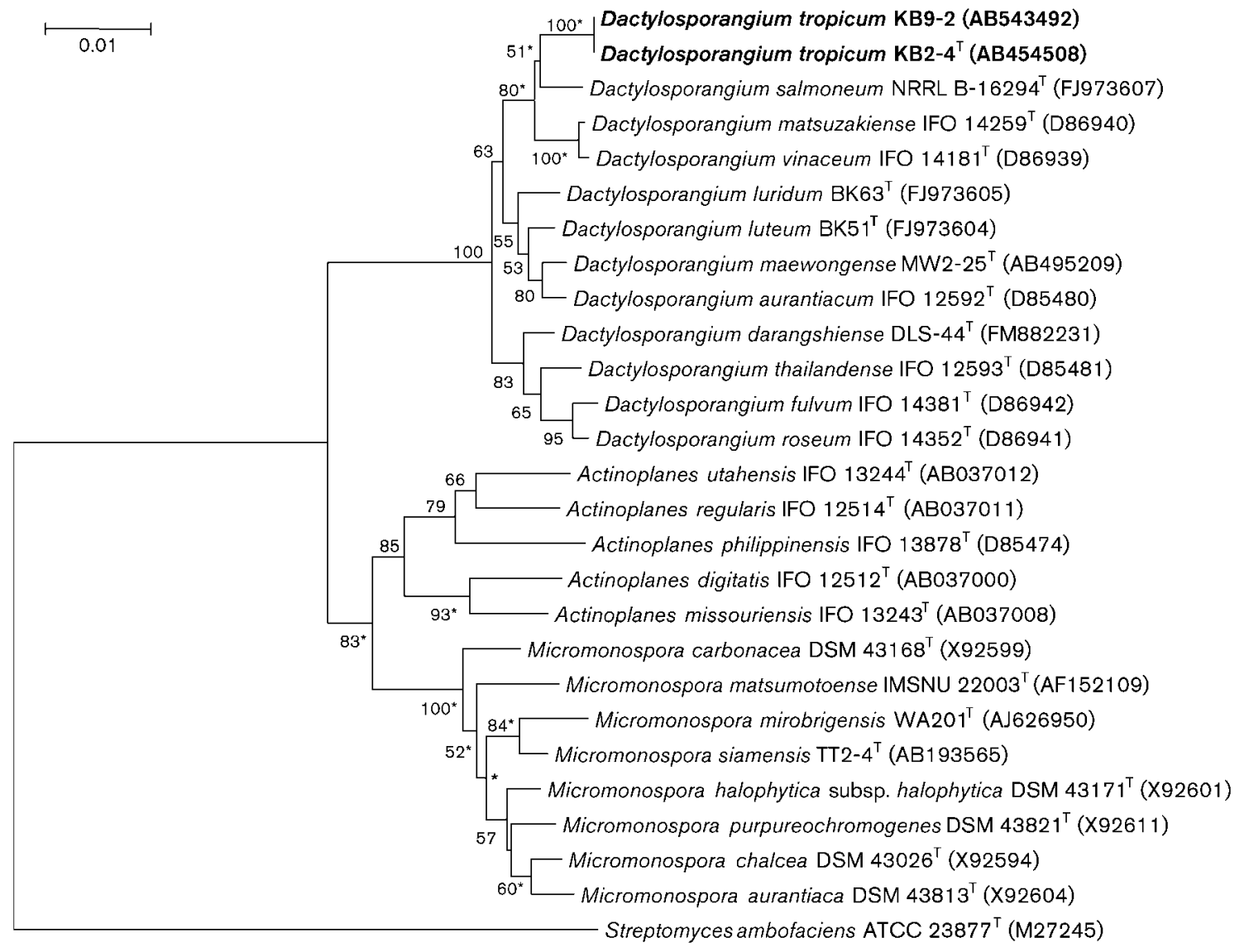

Fig. 2. Neighbour-joining tree (Saitou \& Nei, 1987) based on almost-complete (1401 nt) 16S rRNA gene sequences, showing the relationships between strains KB2-4 ${ }^{\top}$ and KB9-2 and members of the genera Dactylosporangium, Micromonospora and Actinoplanes. Bootstrap values $(>50 \%)$ based on 1000 replicates are shown at branch nodes. Asterisks indicate that the corresponding nodes were also recovered in the tree generated using the maximum-parsimony method. Streptomyces ambofaciens ATCC $23877^{\top}$ was used as an outgroup. Bar, 0.01 substitutions per nucleotide position.

weakly utilizes raffinose, but does not utilize cellobiose, D-fructose, melibiose, D-xylose, lactose or L-rhamnose. Peptonization of milk and hydrolysis of starch are positive. Gelatin liquefaction is negative. Growth is optimum at 25 $30{ }^{\circ} \mathrm{C}$; no growth occurs above $40{ }^{\circ} \mathrm{C}$. The maximum $\mathrm{NaCl}$ concentration for growth is $3 \%(\mathrm{w} / \mathrm{v})$. The cell wall contains glutamic acid, glycine, alanine and meso-diaminopimelic acid. The acyl type of the cell wall is glycolyl. The predominant menaquinones were MK-9 $\left(\mathrm{H}_{8}\right)$ and MK- $9\left(\mathrm{H}_{6}\right)$. The characteristic whole-cell sugars are galactose, glucose, mannose, rhamnose, ribose and xylose. The phospholipid profile contains diphosphatidylglycerol, phosphatidylglycerol, phosphatidylinositol and phosphatidylethanolamine. The fatty acids are iso- $\mathrm{C}_{16: 0}$, anteiso- $\mathrm{C}_{17: 0}$, iso- $\mathrm{C}_{15: 0}$, anteiso- $\mathrm{C}_{15: 0}$, iso- $\mathrm{C}_{17: 0}, \mathrm{C}_{16: 0}, \mathrm{C}_{17: 0}, \mathrm{C}_{18: 0}, 10$-methyl- $\mathrm{C}_{17: 0}, \mathrm{C}_{15: 0}$, iso$\mathrm{C}_{14: 0}, \quad 10$-methyl- $\mathrm{C}_{16: 0}, \quad 10$-methyl- $\mathrm{C}_{18: 0}, \quad \mathrm{C}_{18: 1} \omega 9 c$ and $\mathrm{C}_{17: 1} \omega 8 \mathrm{c}$. The $\mathrm{G}+\mathrm{C}$ content of the type strain is $72.5 \mathrm{~mol} \%$.

The type strain is $\mathrm{KB} 2-4^{\mathrm{T}}\left(=\mathrm{BCC} 34760^{\mathrm{T}}=\mathrm{JCM} 15673^{\mathrm{T}}\right)$, isolated from soil near a hot spring in a tropical forest in Kanchanaburi Province, Thailand.

\section{Acknowledgements}

Research grants from the Thailand Research Fund (TRF) and the Commission on Higher Education, Ministry of Education, Thailand (C. T.) are gratefully acknowledged. We are grateful to the office of the National Research Council of Thailand (NRCT) and the Microbial Resource Management Unit, Scientific Instrument Center, Faculty of Science, King Mongkut's Institute of Technology Ladkrabang for supporting this project.

\section{References}

Arai, T. (1975). Culture Media for Actinomycetes. Tokyo: The Society for Actinomycetes Japan.

Chiaraphongphon, S., Suriyachadkun, C., Tamura, T. \& Thawai, C. (2010). Dactylosporangium maewongense sp. nov., isolated from soil. Int J Syst Evol Microbiol 60, 1200-1205.

Chun, J., Lee, J.-H., Jung, Y., Kim, M., Kim, S., Kim, B. K. \& Lim, Y.-W. (2007). EzTaxon: a web-based tool for the identification of prokaryotes based on $16 \mathrm{~S}$ ribosomal RNA gene sequences. Int J Syst Evol Microbiol 57, 2259-2261. 
Collins, M. D., Pirouz, T., Goodfellow, M. \& Minnikin, D. E. (1977). Distribution of menaquinones in actinomycetes and corynebacteria. J Gen Microbiol 100, 221-230.

Ezaki, T., Hashimoto, Y. \& Yabuuchi, E. (1989). Fluorometric deoxyribonucleic acid-deoxyribonucleic acid hybridization in microdilution wells as an alternative to membrane filter hybridization in which radioisotopes are used to determine genetic relatedness among bacterial strains. Int J Syst Bacteriol 39, 224-229.

Felsenstein, J. (1985). Confidence limits on phylogenies: an approach using the bootstrap. Evolution 39, 783-791.

Goodfellow, M. (1988). Numerical taxonomy and selective isolation of industrially important actinomycete. Actinomycetologica 2, 13-29.

Gordon, R. E., Barnett, D. A., Handerhan, J. E. \& Pang, C. H. N. (1974). Nocardia coeliaca, Nocardia autotrophica, and the nocardin strain. Int J Syst Bacteriol 24, 54-63.

Hamaki, T., Suzuki, M., Fudou, R., Jojima, Y., Kajiura, T., Tabuchi, A., Sen, K. \& Shibai, H. (2005). Isolation of novel bacteria and actinomycetes using soil-extract agar medium. J Biosci Bioeng 99, 485-492.

Hayakawa, M., Sadakata, T., Kajiura, T. \& Nonomura, H. (1991). New methods for the highly selective isolation of Micromonospora and Microbispora from soil. J Ferment Bioeng 72, 320-326.

Itoh, T., Kudo, T., Parenti, F. \& Seino, A. (1989). Amended description of the genus Kineosporia, based on chemotaxonomic and morphological studies. Int J Syst Bacteriol 39, 168-173.

Kämpfer, P. \& Kroppenstedt, R. M. (1996). Numerical analysis of fatty acid patterns of coryneform bacteria and related taxa. Can $J$ Microbiol 42, 989-1005.

Kawamoto, I., Oka, T. \& Nara, T. (1981). Cell wall composition of Micromonospora olivoasterospora, Micromonospora sagamiensis, and related organisms. J Bacteriol 146, 527-534.

Kim, B. Y., Stach, J. E. M., Weon, H. Y., Kwon, S. W. \& Goodfellow, M. (2010). Dactylosporangium luridum sp. nov., Dactylosporangium luteum sp. nov. and Dactylosporangium salmoneum sp. nov., nom. rev., isolated from soil. Int J Syst Evol Microbiol 60, 1813-1823.

Kluge, A. G. \& Farris, F. S. (1969). Quantitative phyletics and the evolution of anurans. Syst Zool 18, 1-32.

Komagata, K. \& Suzuki, K. I. (1987). Lipid and cell-wall analysis in bacterial systematics. Methods Microbiol 19, 161-207.

Kroppenstedt, R. M. (1985). Fatty acid and menaquinone analysis of actinomycetes and related organisms. In Chemical Methods in Bacterial Systematics (Society for Applied Bacteriology Technical Series vol. 20), pp. 173-199. Edited by M. Goodfellow \& D. E. Minnikin. New York: Academic Press.

Kumar, S., Tamura, K., Jakobsen, I. B. \& Nei, M. (2001). MEGA2: Molecular Evolutionary Genetics Analysis software. Bioinformatics 17, 1244-1245.

Lechevalier, M. P. \& Lechevalier, H. A. (1970). Chemical composition as a criterion in the classification of aerobic actinomycetes. Int J Syst Bacteriol 20, 435-443.

Lechevalier, M. P. \& Lechevalier, H. A. (1980). The chemotaxonomy of actinomycetes. In Actinomycete Taxonomy (Special Publication no. 6), pp. 227-291. Edited by A. Dietz \& J. Thayer. Arlington, VA: Society for Industrial Microbiology.

Lechevalier, M. P., DeBievre, C. \& Lechevalier, H. A. (1977). Chemotaxonomy of aerobic actinomycetes: phospholipid composition. Biochem Syst Ecol 5, 249-260.

Minnikin, D. E., Alshamaony, L. \& Goodfellow, M. (1975). Differentiation of Mycobacterium, Nocardia, and related taxa by thin-layer chromatographic analysis of whole-organism methanolysates. J Gen Microbiol 88, 200-204.
Minnikin, D. E., O'Donnell, A. G., Goodfellow, M., Alderson, G., Athalye, M., Schaal, A. \& Parlett, J. H. (1984). An integrated procedure for the extraction of bacterial isoprenoid quinones and polar lipids. J Microbiol Methods 2, 233-241.

Saitou, N. \& Nei, M. (1987). The neighbor-joining method: a new method for reconstructing phylogenetic trees. Mol Biol Evol 4, 406-425.

Sasser, M. (1990). Identification of bacteria by gas chromatography of cellular fatty acids, MIDI Technical Note 101. Newark, DE: MIDI Inc.

Seo, S. H. \& Lee, S. D. (2010). Dactylosporangium darangshiense sp. nov., isolated from rock soil. Int J Syst Evol Microbiol 60, 1256-1260.

Shirling, E. B. \& Gottlieb, D. (1966). Methods for characterization of Streptomyces species. Int J Syst Bacteriol 16, 313-340.

Shomura, T., Kojima, M., Yoshida, J., Ito, M., Amano, S., Totsugawa, K., Niwa, T., Inouye, S., Ito, T. \& Niida, T. (1980). Studies on a new aminoglycoside antibiotic, dactimicin. I. Producing organism and fermentation. J Antibiot (Tokyo) 33, 924-930.

Shomura, T., Yoshida, J., Miyadoh, S., Ito, T. \& Niida, T. (1983). Dactylosporangium vinaceum sp. nov. Int J Syst Bacteriol 33, 309-313.

Shomura, T., Amano, S., Tohyama, H., Yoshida, J., Ito, T. \& Niida, T. (1985). Dactylosporangium roseum sp. nov. Int J Syst Bacteriol 35, 1-4.

Shomura, T., Amano, S., Yoshida, J. \& Kojima, M. (1986). Dactylosporangium fulvum sp. nov. Int J Syst Bacteriol 36, 166-169.

Staneck, J. L. \& Roberts, G. D. (1974). Simplified approach to identification of aerobic actinomycetes by thin-layer chromatography. Appl Microbiol 28, 226-231.

Suriyachadkun, C., Chunhametha, S., Thawai, C., Tamura, T., Potacharoen, W., Kirtikara, K. \& Sanglier, J. J. (2009). Planotetraspora thailandica sp. nov., isolated from soil in Thailand. Int J Syst Evol Microbiol 59, 992-997.

Tamaoka, J. (1994). Determination of DNA base composition. In Chemical Methods in Prokaryotic Systematics, pp. 463-470. Edited by M. Goodfellow \& A. G. O’Donnell. Chichester, UK: Wiley.

Tamaoka, J. \& Komagata, K. (1984). Determination of DNA base composition by reversed-phase high-performance liquid chromatography. FEMS Microbiol Lett 25, 125-128.

Thiemann, J. E. (1970). Dactylosporangium thailandensis should be D. thailandense. Int J Syst Bacteriol 20, 59.

Thiemann, J. E., Pagani, H. \& Beretta, G. (1967). A new genus of the Actinoplanaceae. Dactylosporanguim, gen. nov. Arch Mikrobiol 58, 42-52.

Thompson, J. D., Higgins, D. G. \& Gibson, T. J. (1994). CLUSTAL W: improving the sensitivity of progressive multiple sequence alignment through sequence weighting, position-specific gap penalties and weight matrix choice. Nucleic Acids Res 22, 4673-4680.

Thompson, J. D., Gibson, T. J., Plewniak, F., Jeanmougin, F. \& Higgins, D. G. (1997). The CLUSTAL_X windows interface: flexible strategies for multiple sequence alignment aided by quality analysis tools. Nucleic Acids Res 25, 4876-4882.

Uchida, K. \& Aida, K. (1984). An improved method for the glycolate test for simple identification of the acyl type of bacterial cell walls. J Gen Appl Microbiol 30, 131-134.

Verlander, C. P. (1992). Detection of horseradish peroxidase by colorimetry. In Nonisotopic DNA Probe Techniques, pp. 185-201. Edited by L. J. Kricka. New York: Academic Press.

Williams, S. T. \& Cross, T. (1971). Actinomycetes. In Methods in Microbiology, vol. 4, pp. 295-334. Edited by C. Booth. London: Academic Press.

Zhi, X.-Y., Li, W.-J. \& Stackebrandt, E. (2009). An update of the structure and 16S rRNA gene sequence-based definition of higher ranks of the class Actinobacteria, with the proposal of two new suborders and four new families and emended descriptions of the existing higher taxa. Int J Syst Evol Microbiol 59, 589-608. 